\title{
Spectrophotometric Determination of Tetracycline by Coupling with Diazotised 4-Aminoantipyrine in Presence of Cetylpyridinium Chloride
}

\author{
Nabeel S. Othman \\ Rasha J. Al-Ashow \\ Department of Chemistry \\ College of Science \\ University of Mosul
}

(Received 26/6/2011;Accepted 31/10/2011)

\begin{abstract}
A spectrophotometric method for the determination of microgram amounts of tetracycline $-\mathrm{HCl}(\mathrm{TCH})$ has been proposed. The method is based on coupling of tetracycline-HCl with diazotized 4-aminoantipyrine in presence of cetylpyridinium chloride in alkaline medium. The molar absorptivity of the formed dye reached to $1.92 \times 10^{4} 1 . \mathrm{mol}^{-1}$. $\mathrm{cm}^{-1}$ at $537 \mathrm{~nm}$ and Beer's law is obeyed within the range of 10-300 $\mu \mathrm{g}$ of tetracycline- $\mathrm{HCl}$ $/ 10 \mathrm{ml}$ (i.e. $1.0-30 \mathrm{ppm}$ ). The colour reaction was highly stable, a relative error ranged from -2.5 to $+0.21 \%$ and a relative standard deviation of \pm 0.37 to $\pm 0.73 \%$, depending on concentration level of tetracycline- $\mathrm{HCl}$. The proposed method has been applied successfully to the determination of tetracycline- $\mathrm{HCl}$ in pharmaceutical preparations.
\end{abstract}

Keywords: Tetracycline-HCl; 4-aminoantipyrine; diazo-coupling; spectrophotometry.

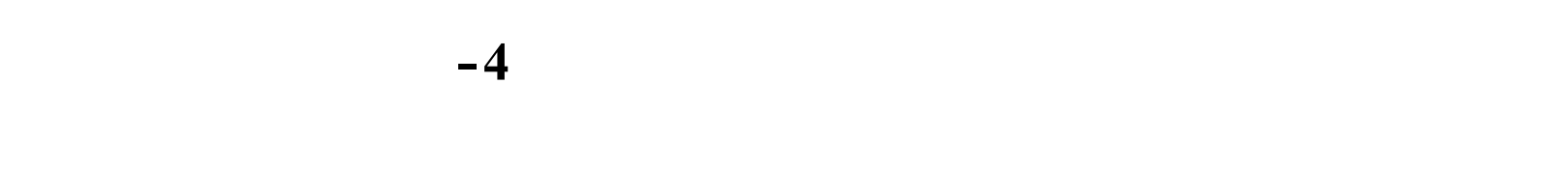

\section{الملغص}

قم اقتراح طريقة طيفيه لقدير كميلت متناهية في الصغر من هيدروكلوريد التترلسايكلين. تتعمد

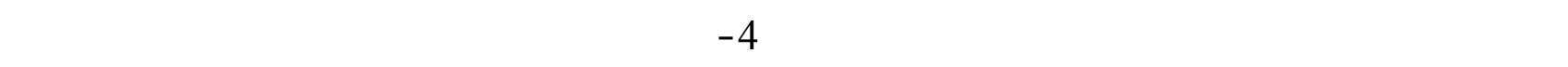

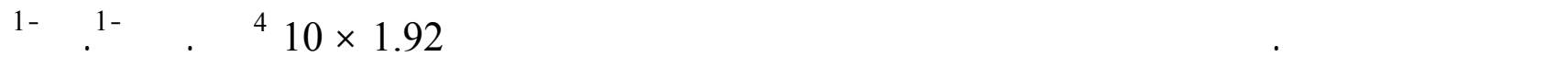
عند الطول الموجي الاغظم 537 نانوميتر. وتتع الطريقه قانون بير في مدى الترلكيز من 10 اللى 300

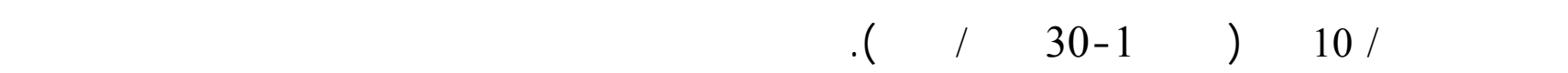

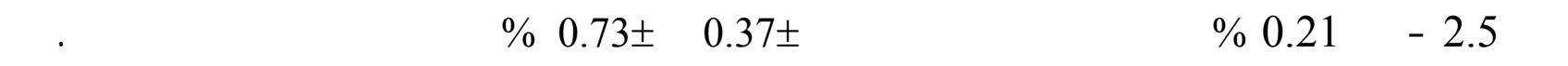
ظبيق الطريقة بنجاح في نقدير هيدروكلوريد التترلسايكلين في المستحضرات الصيدلانية. 


\section{INTRODUCTION}

Tetracycline antibiotics are potent, broad spectrum antibacterial agents effective against a host of Gram positive and Gram negative aerobic and anaerobic bacteria. As a result, the tetracyclines are drugs of choice, or well accepted alternatives for a variety of infectious diseases (Albert, 1953). Assay of tetracycline has previously been achieved by several analytical techniques such as high performance liquid chromatography (Shalaby et al., 2011 ), RPHPLC ( Johnathan and Yugang, 2007 ; Kazuo et al., 1992), LC (Innocenzo and Fabio, 2009) LC-Mass (Pena et al., 2007), flourimetry (Regos et al., 1978), adsorptive voltammetry (Parviz et al., 2007), flow injection (Saisunee et al., 2006; Jose et al., 2009 ; Prinya et al 2008). However, many of these methods require expensive equipments and skilled operation. The most widely methods used for the determination of tetracycline are spectrophotometric methods such as: complexation with iron (Ronald, 2007), oxidative coupling (Ayad et al., 1986), diazo- coupling (Al-Abbasi, 2009), charge transfer complex (Khairi, 2008), kinetic spectrophotometric method (Yongnian et al., 2010) However, some of these methods suffer form one or more disadvantage such as insufficient sensitivity, poor selectivity or using of solvent extraction procedures. Therefore, a simple and accurate method for assaying of tetracycline in different pharmaceutical preparations is necessary for routine analysis.

\section{Apparatus}

\section{EXPERIMENTAL}

All absorption measurements were obtained by using a double beam CECIL CE7200 UV-Visible Recording Spectrophotometer with $1.0 \mathrm{~cm}$ matched quartz cells and the $\mathrm{pH}$ measurements were performed by using HANNA Instrument $\mathrm{pH} 211$ microprocesser $\mathrm{pH}$ meter.

\section{Reagent}

All Chemicals used are of analytical-reagent grade .

A pure tetracycline - $\mathrm{HCl}(\mathrm{TCH})$ was obtained from the State Company for Drug Industries and Medical Applicances (SDI), Sammara, Iraq .A solution of $100 \mu \mathrm{g} \mathrm{ml}^{-1}$ was prepared by dissolving $0.01 \mathrm{~g}$ of tetracycline $-\mathrm{HCl}$ in $100-\mathrm{ml}$ distilled water. Sodium carbonate $(1 \mathrm{M})$ and different interferences solution $\left(1000 \mu \mathrm{g} \mathrm{ml}^{-1}\right)$ were prepared by dissolving the proper amounts in distilled water. The diazotised 4-aminoantipyrine ( 2.5 $\mathrm{mM}$ ) solution was prepared by dissolving $0.05 \mathrm{~g}$ of 4-aminoantipyrine (Fluka) in $60 \mathrm{ml}$ distilled water then $3 \mathrm{ml}$ of concentrated hydrochloric acid was added followed by heating. Finally the mixture was transferred to a $100-\mathrm{ml}$ volumetric flask and cooled at $0-5{ }^{\circ} \mathrm{C}$ in an ice-bath. A $0.017 \mathrm{~g}$ sodium nitrite was added and the mixture was stirred vigorously After 5 minutes, the solution was made up to $100 \mathrm{ml}$ with cold distilled water and was kept in brown bottle in a refrigerator for 1 hour before using, and it is stable for at least five days.

\section{General procedure and calibration graph}

The aqueous solution $(0.1-3 \mathrm{ml})$ containing tetracycline-HCl $\left(100 \mu \mathrm{g} . \mathrm{ml}^{-1}\right)$ was transferred into a series of $10-\mathrm{ml}$ calibrated flasks. To each flask $1 \mathrm{ml}$ of diazotised 4aminoantipyrine solution $(2.5 \mathrm{mM}), 2 \mathrm{ml}$ of sodium carbonate solution $(1 \mathrm{M})$ and $4 \mathrm{ml}$ of CPC $\left(1 \times 10^{-3} \mathrm{M}\right)$ were added then the volume was completed to the mark with distilled 
water. The absorbance was measured at $537 \mathrm{~nm}$ against a reagent blank which was prepared in a similar way but without the addition of tetracycline-HCl. The calibration graph as shown in Fig. ( 1) was linear over the range of $10-300 \mu \mathrm{g}$ of tetracycline-HCl /10 $\mathrm{ml}$ (i.e $1-30 \mathrm{ppm}$ ). The apparent molar absorptivity referred to tetracycline $-\mathrm{HCl}$ has been found to be $1.92 \times 10^{4} 1 . \mathrm{mol}^{-1} \cdot \mathrm{cm}^{-1}$.

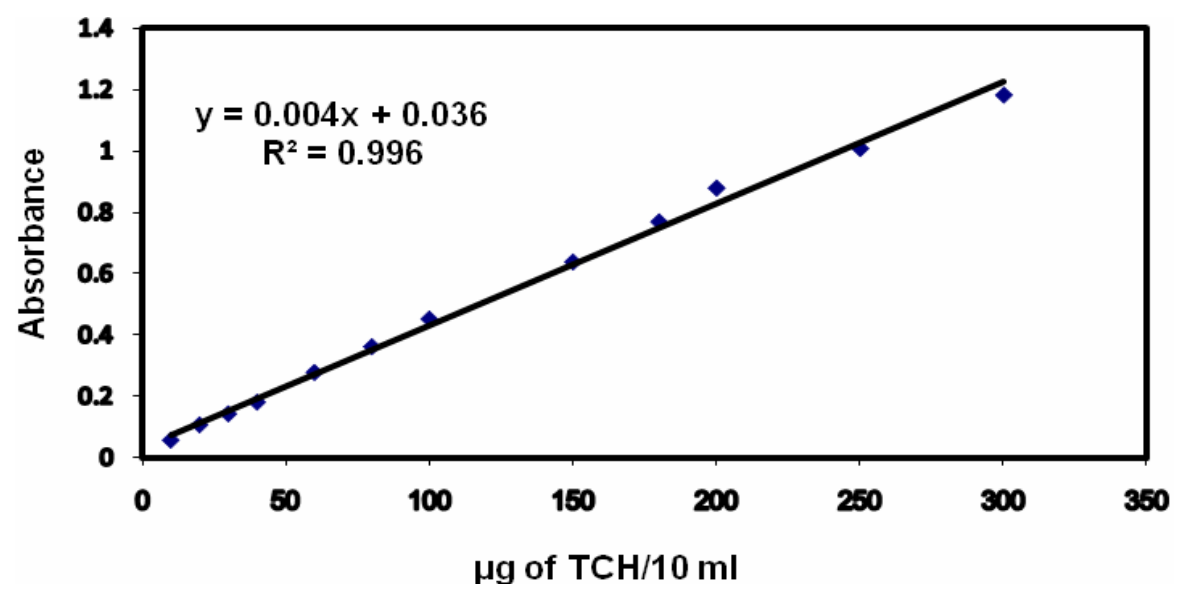

Fig. 1: Calibration graph for tetracycline $-\mathrm{HCl}$ determination using the proposed method.

\section{Determination of tetracycline in capsule}

Weight and mix the contents of five capsule (each one contains $250 \mathrm{mg}$ tetracycline $\mathrm{HCl}$ ), an accurately weighed amount of powder equivalent to $0.01 \mathrm{~g}$ tetracycline - $\mathrm{HCl}$ was dissolved in $100 \mathrm{ml}$ distilled water in a volumetric flask. A suitable aliquot of solution was taken and the recommended procedure was followed for analysis of the drug .

\section{Determination of tetracycline in ointment}

Mixed well the contents of four containers of tetracycline ointment, an accurately weighed amount equivalent to $0.01 \mathrm{~g}$ tetracycline - $\mathrm{HCl}$ was dissolved in a mixture of $3 \mathrm{ml}$ ethanol with $50 \mathrm{ml}$ distilled water, then the mixture was warmed and filtered into a 100- $\mathrm{ml}$ volumetric flask and the volume was completed to the mark with distilled water. A suitable aliquot of solution was taken and the recommended procedure was followed for analysis of the drug.

\section{RESULTS AND DISCUSSION}

The effect of various variables on the colour development was tested to establish the optimum conditions for the determination of $\mathrm{TCH}$ by coupling with diazotized 4aminoantipyrine reagent. 


\section{Principle of the method}

The method included the following steps:

- Preparation of diazotised 4-aminoantipyrine<smiles>Cc1c(N)c(=O)n(-c2ccccc2)n1C</smiles>

\section{4-aminoantipyrine}

Diazotised 4-aminoantipyrine

- Coupling of tetracycline with diazotised 4-aminoantipyrine

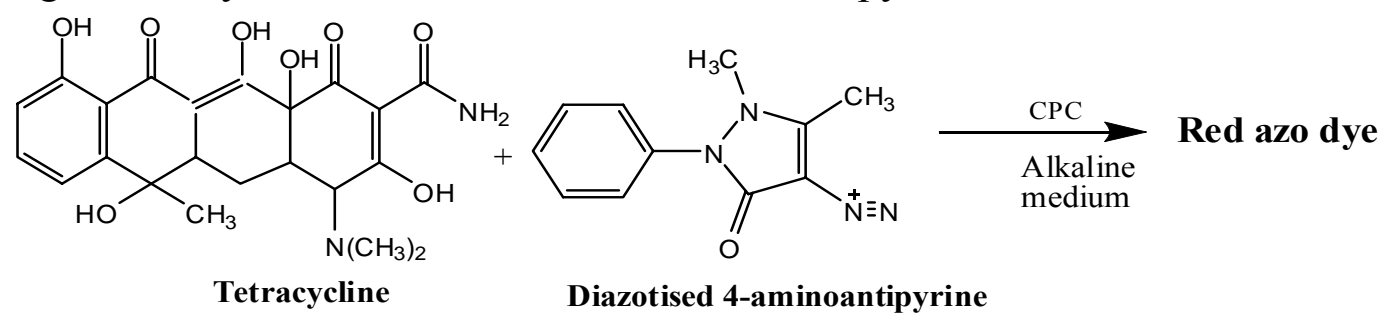

\section{Choice of diazotised agent and amount}

Several aromatic diazotised agents have been tested for optimum conditions. The results in Table 1 show that $\mathrm{p}$-phenyldiamine give the highest intensity but with low value of colour contrast, while 4-aminoantipyrine gives good sensitive reaction $\left(\varepsilon=1.85 \times 10^{4}\right.$ 1. $\left.\mathrm{mol}^{-1} \cdot \mathrm{cm}^{-1}\right)$ with high value of colour contrast $(165 \mathrm{~nm})$ in alkaline medium. Therefore, it has been selected for the subsequent experiments.

Table 1: The selection of diazotised agent.

\begin{tabular}{|c|c|c|c|c|}
\hline Reagent( 2.5 mM) & Absorbance & $\lambda_{\max }(\mathbf{n m})$ & $\Delta \lambda_{\max }(\mathbf{n m})$ & $\varepsilon\left(\mathbf{l . m o l}^{\left.\mathbf{- 1} . \mathbf{c m}^{-1}\right)}\right.$ \\
\hline m-Nitroaniline & 0.261 & 352 & 99 & $1.26 \times 10^{4}$ \\
\hline p-Phenyldiamine & 0.404 & 352 & 42 & $1.95 \times 10^{4}$ \\
\hline Sulphanilic acid & 0.114 & 352.5 & 102.5 & $0.55 \times 10^{4}$ \\
\hline 4-aminoantipyrine & 0.384 & 537 & 165 & $1.85 \times 10^{4}$ \\
\hline
\end{tabular}

$* \Delta \lambda_{\max }=$ Colour contrast $=\lambda_{\max } \mathrm{S}-\lambda_{\max } \mathrm{B}$ where $\mathrm{S}=$ The dye, $\mathrm{B}=\mathrm{Blank}$.

The effect of different amounts $(0.5-2 \mathrm{ml})$ of diazotised 4-aminoantipyrine reagent on the absorbance of solutions containing different amounts of tetracycline- $\mathrm{HCl}$ (50-250 $\mu \mathrm{g} / 10 \mathrm{ml})$ have been studied. The obtained results indicated that the absorbance increases 
with increasing the reagent concentration (diazotised 4-aminoantipyrine) and reached a maximum on using a volume of $1.0 \mathrm{ml}$ of $2.5 \mathrm{mM}$ diazotised 4-aminantipyrine, which also gives the highest value of determination coefficient $\left(\mathrm{r}^{2}=0.9938\right)$. Therefore, $1.0 \mathrm{ml}$ reagent was recommended for the subsequent experiments.

\section{Effect of base}

Preliminary experiments have been shown that TCH gives coloured dye with diazotised 4-aminoantipyrine only in basic medium. Various bases (strong and weak) have been used and their results in Table 2 indicate that $2 \mathrm{ml}$ of $\mathrm{Na}_{2} \mathrm{CO}_{3}(1 \mathrm{M})$ give the highest intensity of the coloured dye, therefore this volume has been recommended for the subsequent experiments.

Table 2: The effect of base on absorbance .

\begin{tabular}{|c|c|c|c|c|}
\hline \multirow{2}{*}{$\begin{array}{c}\text { Amount of base } \\
\text { used } \\
(\mathbf{m l})\end{array}$} & \multicolumn{4}{|c|}{ Absorbance/base used (1M) } \\
\cline { 2 - 5 } & $\mathbf{N a O H}$ & $\mathbf{K O H}$ & $\mathbf{N a}_{\mathbf{2}} \mathbf{C O}_{\mathbf{3}}$ & $\mathbf{N a H C O}_{\mathbf{3}}$ \\
\hline 0.25 & 0.015 & 0.018 & 0.242 & 0.009 \\
\hline 0.5 & 0.103 & 0.019 & 0.379 & 0.194 \\
\hline 1.0 & 0.061 & 0.053 & 0.386 & 0.350 \\
\hline 2.0 & 0.057 & 0.045 & 0.413 & 0.354 \\
\hline 3.0 & 0.050 & 0.032 & 0.413 & 0.388 \\
\hline $\mathrm{pH}$ range & $(2.17-13.16)$ & $(1.98-13.20)$ & $(6.68-10.73)$ & $(3.75-9.73)$ \\
\hline$* \Delta \lambda_{\max }$ & 135 & 137 & 165 & 165 \\
\hline
\end{tabular}

$* \Delta \lambda_{\max }=$ Colour contrast $\lambda_{\max } \mathrm{S}-\lambda_{\max } \mathrm{B}$

where $\mathrm{S}=$ The dye, $\mathrm{B}=\mathrm{Blank}$

\section{Effect of surfactant}

The effect of several types of surfactants on colour intensity of the dye has been investigated. (Table 3 and Fig. 2).

Table 3: The effect of surfactant on dye absorbance.

\begin{tabular}{|c|c|c|c|c|c|c|c|c|c|}
\hline \multirow{2}{*}{ * Order } & \multicolumn{3}{|c|}{$\begin{array}{c}\text { Absorbance / } \mathrm{ml} \text { of } \\
\text { CPC }\left(1 \times 10^{-3} \mathrm{M}\right)\end{array}$} & \multicolumn{3}{|c|}{$\begin{array}{l}\text { Absorbance/ml of SDS } \\
\qquad\left(1 \times 10^{-3} \mathrm{M}\right)\end{array}$} & \multicolumn{3}{|c|}{$\begin{array}{l}\text { Absorbance/ml of } \\
\text { Triton-X100 (1\%) }\end{array}$} \\
\hline & $1 \mathrm{ml}$ & $3 \mathrm{ml}$ & $4 \mathrm{ml}$ & $1 \mathrm{ml}$ & $3 \mathrm{ml}$ & $4 \mathrm{ml}$ & $1 \mathrm{ml}$ & $3 \mathrm{ml}$ & $4 \mathrm{ml}$ \\
\hline I & 0.282 & 0.263 & 0.242 & 0.409 & 0.407 & 0.380 & 0.409 & 0.407 & 0.392 \\
\hline II & 0.283 & 0.275 & 0.244 & 0.405 & 0.398 & 0.386 & 0.389 & 0.405 & 0.420 \\
\hline III & 0.429 & 0.445 & 0.458 & 0.401 & 0.386 & 0.374 & 0.397 & 0.401 & 0.415 \\
\hline
\end{tabular}

Note Absorbance without surfactant $=0.412$

$I^{*}=$ Sample (S) + Surfactant ( Sur.) + diazotised (R) + Base (B )

II $=\mathrm{S}+\mathrm{R}+$ Sur. $+\mathrm{B}$

$\mathbf{I I}=\mathrm{S}+\mathrm{R}+\mathrm{B}+\mathrm{Sur}$. 


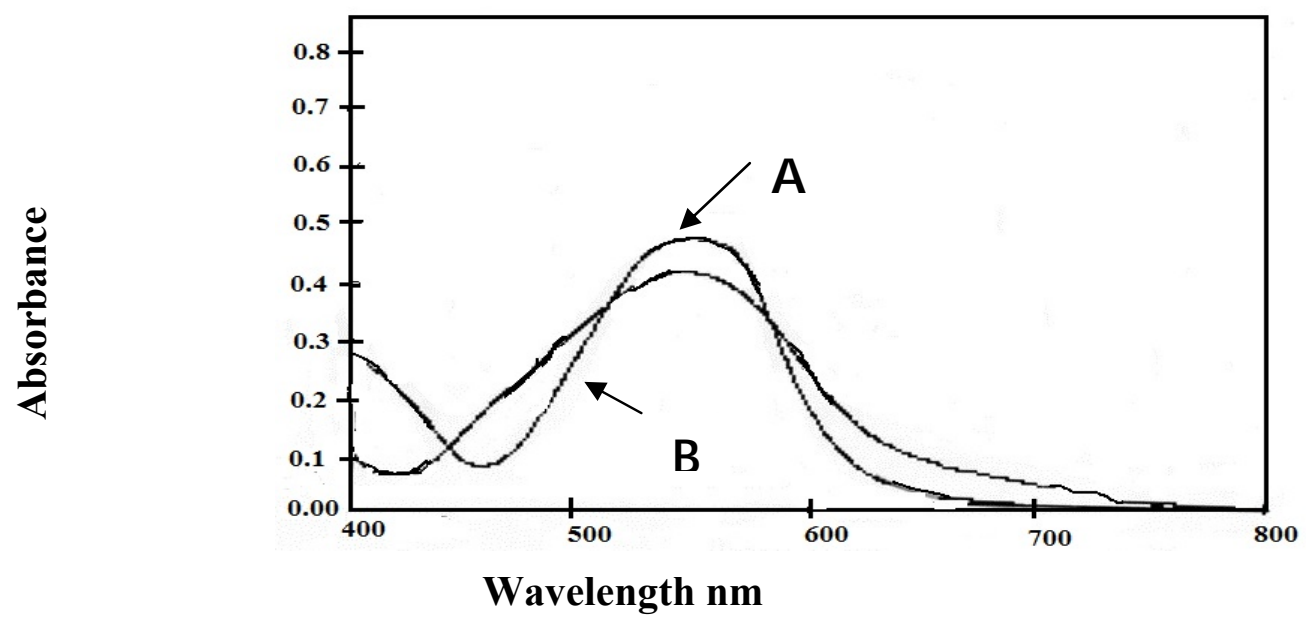

Fig. 2: The effect of CPC on absorbance (order III)
A- Sample with CPC B-Sample without CPC

The results indicate that the addition of CPC in the order (III) increases the intensity of the formed dye, therefore it has been recommended to use $4 \mathrm{ml}$ of CPC $\left(1 \times 10^{-3} \mathrm{M}\right)$ in this order in subsequent experiments.

\section{Effect of time and amount of TCH on absorbance}

The effect of time on the development and stability period of the formed coloured dye was investigated under optimum experimental conditions described before. The formation of coloured dye being complete after mixing the components of reaction and the absorbance of the coloured species remained constant for at least 60 minutes. (Table 4).

Table 4: The effect of time on absorbance.

\begin{tabular}{|c|c|c|c|}
\hline \multirow{2}{*}{ Time/min. } & \multicolumn{3}{|c|}{ Absorbance/ $\boldsymbol{\mu g}$ of tetracycline-HCl } \\
\hline & $\mathbf{1 0 0}$ & $\mathbf{2 0 0}$ & $\mathbf{2 5 0}$ \\
\hline 0 & 0.454 & 0.776 & 1.006 \\
\hline 5 & 0.458 & 0.778 & 1.004 \\
\hline 10 & 0.456 & 0.774 & 0.998 \\
\hline 20 & 0.457 & 0.775 & 0.995 \\
\hline 30 & 0.454 & 0.776 & 0.993 \\
\hline 40 & 0.456 & 0.774 & 0.990 \\
\hline 50 & 0.455 & 0.775 & 0.989 \\
\hline 60 & 0.450 & 0.774 & 0.987 \\
\hline
\end{tabular}




\section{Final Absorption Spectra}

An absorption spectra of the formed coloured dye by coupling of TCH with diazotised 4-aminoantipyrine in the presence of CPC and in basic medium, against its corresponding reagent blank shows a maximum absorbance at $537 \mathrm{~nm}$ in contrast to the reagent blank which shows maximum absorbance at $425 \mathrm{~nm}$ ( Fig 3).

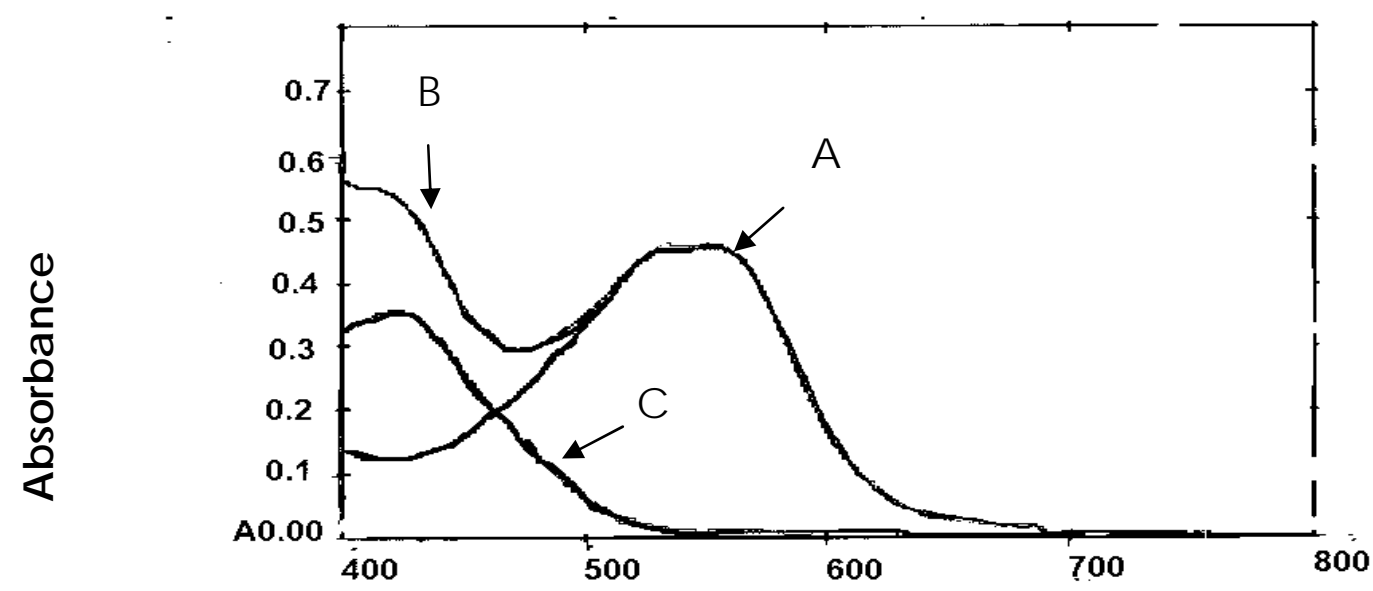

\section{Wavelenthg ( $\mathrm{nm})$}

Fig. 3: Absorption spectra of $100 \mu \mathrm{g} \mathrm{TCH}$ treated according to the recommended procedure and measured against (A) blank (B) distilled water and (C) blank measured against distilled water

\section{INTERFERENCE}

The criterion of interference was an error of not more than $\pm 5.0 \%$ in the absorbance. To test the efficiency and selectivity of the proposed analytical method, a systematic study of excipients (e.g. , glucose, lactose , gum Arabic and starch) at various levels, that usually present in dosage forms. Experimental results showed that there was no interference from additives or excipients up to $1500 \mu \mathrm{g}$ in the present method as shown in Table 5.

Table 5: Effect of foreign compounds for assay of tetracycline-HCl.

\begin{tabular}{|c|c|c|c|}
\hline $\begin{array}{c}\text { Foreign } \\
\text { compound }\end{array}$ & \multicolumn{3}{|c|}{ Recovery (\%) of 100 $\boldsymbol{\mu g}$ tetracycline-HCI per $\boldsymbol{\mu g}$ foreign } \\
compound added
\end{tabular}




\section{Accuracy and precision}

To check the accuracy and precision of the calibration curve, TCH was determined at two different concentrations. The results illustrated in Table (6) indicate that the method is satisfactory.

Table 6: Accuracy and precision of the calibration curv.

\begin{tabular}{|c|c|c|c|}
\hline $\begin{array}{c}\text { Pharmaceutical } \\
\text { preparation }\end{array}$ & $\begin{array}{c}\text { Amount } \\
\text { taken mg }\end{array}$ & $\begin{array}{c}\text { Relative } \\
\text { error,\%* }\end{array}$ & $\begin{array}{c}\text { Relative standard } \\
\text { deviation,\%* }\end{array}$ \\
\hline $\begin{array}{c}\text { Samacycline } \\
\text { 250mg /Capsules } \\
\text { ( S.D.I Iraq) }\end{array}$ & 50 & -2.1 & \pm 0.73 \\
\cline { 2 - 4 } & 100 & 0.21 & \pm 0.37 \\
\hline $\begin{array}{c}\text { Apecycline } \\
\text { 250mg/Capsoules } \\
\text { (India) }\end{array}$ & 50 & -2.5 & \pm 0.73 \\
\cline { 2 - 4 } & 100 & -1.09 & \pm 0.48 \\
\hline
\end{tabular}

*Average of four determinations

\section{Nature of the azo dye}

Job's and mole - ratio methods (Hargis, 1988) indicate that the azo dye has a Also the Job's method composition of 1:1 [TCH] to diazotised 4-aminoantipyrine. reagent. indicated that the composition of CPC with tetracycline was equal to the ratio 1:1 There for ,the suggested structure was as shown below:

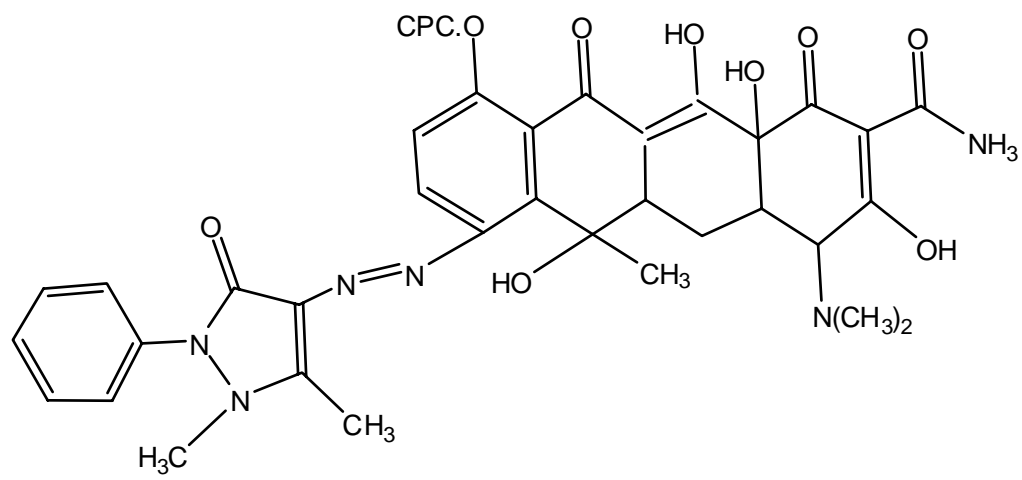

Red azo dye

The average stability constant of the dye in aqueous solution, under the established experimental condition, is $0.123 \times 10^{6}$ Molar $^{-1}$ 


\section{The effect of organic solvents}

Different organic solvents have been examined to evalute their effects on the spectrum of the resulting azo dye, the results are given in Table 7 and Fig. 4

Table 7: The effect of organic solvents compared with water.

\begin{tabular}{|c|c|c|c|}
\hline Solvent & $\boldsymbol{\lambda} \mathbf{m a x}, \mathbf{n m}$ & Absorbance & $\mathbb{E} \mathbf{I . m o l}_{\mathbf{~} \mathbf{.} . \mathbf{c m}^{\mathbf{- 1}}}$ \\
\hline Ethanol & 554 & 0.396 & $1.91 \times 10^{4}$ \\
\hline Formic acid & 561 & 0.233 & $1.12 \times 10^{4}$ \\
\hline Methanol & 606 & 0.396 & $1.91 \times 10^{4}$ \\
\hline Acetic acid & 612 & 0.051 & $0.25 \times 10^{4}$ \\
\hline Water & 537 & 0.451 & $2.178 \times 10^{4}$ \\
\hline
\end{tabular}

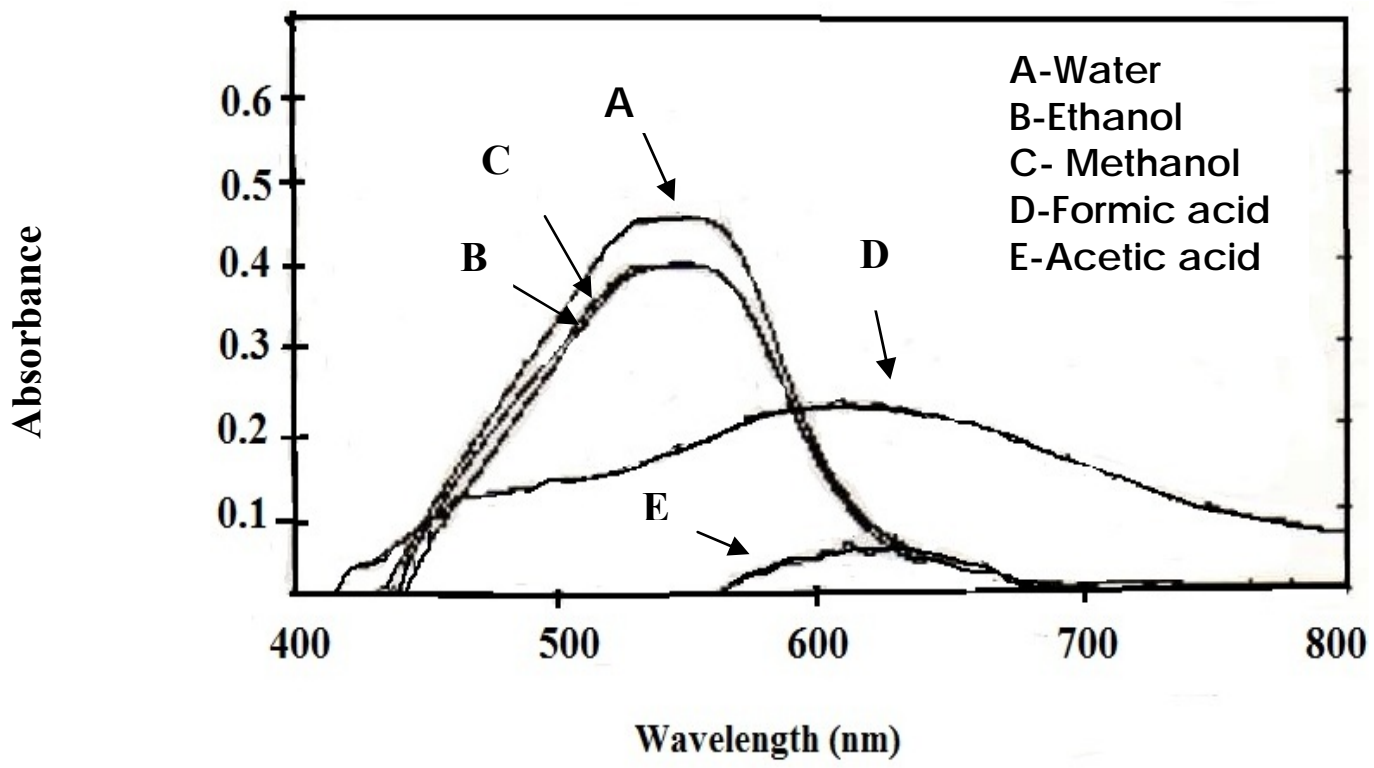

Fig. 4: The effect of solvents

Although formic acid and acetic acid caused red shift, water still used in the subsequent experiments according to the highest sensitivity.

\section{Application of the method}

The proposed method was applied to determine tetracycline- $\mathrm{HCl}$ in its pharmaceutical preparations(capsules and skin ointment). The results which are shown in Table 8 indicate that a good recovery was obtained. 
Table 8:Analytical applications of the proposed method.

\begin{tabular}{|c|c|c|c|}
\hline Pharmaceutical preparation & $\begin{array}{c}\text { Amount taken } \\
(\boldsymbol{\mu g})\end{array}$ & $\begin{array}{c}\text { Amount } \\
\text { measured }\end{array}$ & Recovery \\
\hline $\begin{array}{c}\text { Samacycline } \\
\text { 250mg /Capsules } \\
\text { (S.D.I Iraq) }\end{array}$ & 50 & 49.7 & 99.4 \\
\cline { 2 - 4 } & 100 & 100.2 & 100.2 \\
\hline $\begin{array}{c}\text { Apecycline } \\
\text { 250mg/Capsules }\end{array}$ & 50 & 49.7 & 99.4 \\
\cline { 2 - 4 } & 100 & 99.9 & 99.9 \\
\hline $\begin{array}{c}\text { Samacycline } \\
\text { ( S.DECTOR India) }\end{array}$ & 50 & 49.7 & 100 \\
\cline { 2 - 4 }
\end{tabular}

\section{Average of four determinations}

The results obtained are in the agreement with certified values compared with standard addition method (Fig. 5 and Table 9).
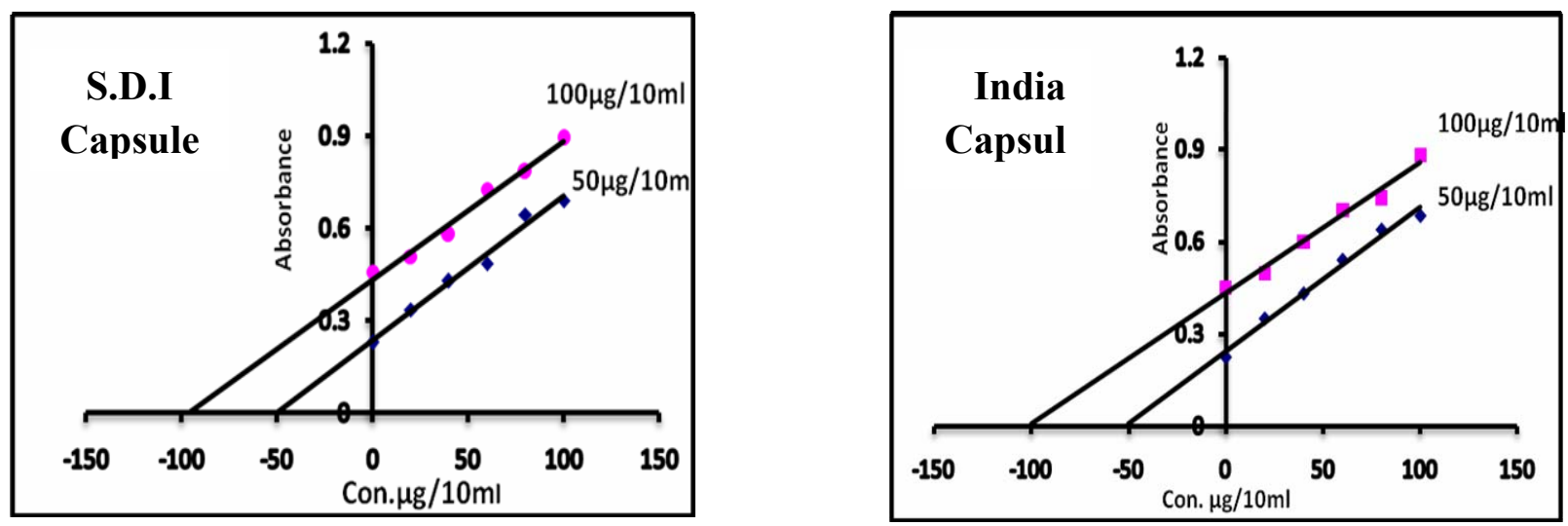

Fig. 5 : Standard addition plot for the recovery of 50 and $100 \mathrm{mg}$ of TCH in S.D.I Iraq capsule and PVT.SECTOR India capsule. 
Table 9: The results of standard addition method.

\begin{tabular}{|c|c|c|c|}
\hline $\begin{array}{c}\text { Pharmaceutical } \\
\text { preparation }\end{array}$ & $\begin{array}{c}\text { Amount } \\
\text { taken (mg) }\end{array}$ & $\begin{array}{c}\text { Amount } \\
\text { measured(mg) }\end{array}$ & Recovery, \% \\
\hline $\begin{array}{c}\text { Samacycline } \\
\text { 250mg /Capsules } \\
\text { S.D.I Iraq }\end{array}$ & 50 & 50 & 100 \\
\cline { 2 - 4 } & 100 & 98.5 & 98.5 \\
\hline $\begin{array}{c}\text { Apecycline } \\
\text { 250mg/Capsules } \\
\text { PVT. SECTOR. India }\end{array}$ & 100 & 50 & 101 \\
\cline { 2 - 4 }
\end{tabular}

The performance of the proposed method for determination of tetracycline in ointment was assessed by calculation of the t-test compared with the standard method (British Pharmacopeia, 2000) (spectrophotometric method ) for 95\% confidence level with eight degrees of freedom. The results (Table 10) showed that the t-value was less than the critical value, indicating no significant difference between the proposed and standard method for the determination of tetracycline in ointment.

Table 10: Analytical applications of the proposed method and t-values experimental.

\begin{tabular}{|c|c|c|c|}
\hline \multirow{2}{*}{ Drug } & \multicolumn{2}{|c|}{ Recovery, \%* } & \multirow{2}{*}{ t. exp } \\
\cline { 2 - 3 } & $\begin{array}{c}\text { Present } \\
\text { method }\end{array}$ & $\begin{array}{c}\text { British } \\
\text { pharmacopeia } \\
\text { method }\end{array}$ & \\
\hline $\begin{array}{c}\text { Samacycline } \\
\text { Skin ointment } \\
\text { S.D.I (Iraq) }\end{array}$ & 99.70 & 99.55 & 0.459 \\
\hline
\end{tabular}

*Average of five determinations of $100 \mu \mathrm{g}$ TCH.

\section{Comparison of the methods}

Table(11) shows the comparison between some of analytical variables for the present method with that of another literature spectrophotometric methods. 
Table 11: Comparison of the methods.

\begin{tabular}{|c|c|c|c|c|c|c|}
\hline Technique & Reaction & Reagent & $\begin{array}{l}\lambda_{\max } \\
(\mathrm{nm})\end{array}$ & Berr's law & $\begin{array}{c}\varepsilon\left(\text { l.mol-1 }^{-1}\right. \\
\left.. \mathrm{cm}^{-1}\right)\end{array}$ & Reference \\
\hline FI**/Spec.* & Complexation & Aluminum chloride & 376 & & ............. & $\begin{array}{l}\text { Saisunee, } \\
\text { et al., } 2006\end{array}$ \\
\hline FI/Spec. & Oxidation & Chloramine $-\mathrm{T}$ & 535 & $6.62 \times 10^{-5}-.72 \times 10^{-4}$ & ............... & $\begin{array}{c}\text { Jose } \\
\text { et al., } 2009\end{array}$ \\
\hline Spec. & $\begin{array}{l}\text { Oxidative } \\
\text { coupling }\end{array}$ & 4-Aminoantipyrine & 520 & $0.04-12 \mathrm{mg} / \mathrm{ml}$ & & $\begin{array}{c}\text { Ayad } \\
\text { et al., } 1986\end{array}$ \\
\hline Spec. & Complexation & $\mathrm{Fe}^{+3}$ & 435 & $2.81 \times 10^{-3}-.50 \times 10^{-4}$ & ……... & $\begin{array}{l}\text { Ronalad, } \\
2007\end{array}$ \\
\hline Spec. & $\begin{array}{l}\text { Charge transfer } \\
\text { complexation }\end{array}$ & Chloranilic acid & 540 & $2.5-30.0 \mathrm{mg} / \mathrm{ml}$ & ............. & $\begin{array}{l}\text { Khairi, } \\
2008\end{array}$ \\
\hline Spec. & Diazo coupling & $\begin{array}{l}\text { Diazotised p-nitro } \\
\text { aniline }\end{array}$ & 569 & $2-400 \mu \mathrm{g} / 25 \mathrm{ml}$ & $7.8 \times 10^{4}$ & $\begin{array}{l}\text { Al-Abbasi, } \\
2009\end{array}$ \\
\hline FI/ Spec. & & Uranyl acetate & 410 & $1.0-3.0 \mu \mathrm{g} / \mathrm{ml}$ & $\ldots \ldots \ldots . .$. & $\begin{array}{l}\text { Prinya } \\
\text { et al., } 2008\end{array}$ \\
\hline Spec. & Diazo coupling & $\begin{array}{l}\text { Diazotised 4- } \\
\text { aminoantipyrine }\end{array}$ & 537 & $1.0-3.0 \mu \mathrm{g} / \mathrm{ml}$ & $1.923 \times 10^{4}$ & $\begin{array}{l}\text { Present } \\
\text { method }\end{array}$ \\
\hline
\end{tabular}

*Spec. $=$ Spectrophtometric method

** $\mathrm{FI}=$ Flow injection method

The results indicate that the proposed method has a good sensitivity and has a wide application part in determination of drug under investigation in its pharmaceutical preparations.

\section{CONCLUSION}

The proposed method for the determination of tetracycline $-\mathrm{HCl}$ is simple and has a good sensitivity. The proposed method has advantageous over some of the reported visible spectrophotometric methods with respect to reproducibility, precision, accuracy and stability of the coloured species. The proposed method is suitable for the determination of tetracycline $-\mathrm{HCl}$ in pure form and in its pharmaceutical preparations.

\section{REFERENCES}

Al-Abbasi, K. (2009). Spectrophotometric determination of tetracycline by azo dye formation with diozotised p-nitroaniline -application to pharmaceutical preparation and biological fluids. J. Raf. Sci., 20, 61-74.

Albert, A. ( 1953). Avidity of tetracycline and aureomycin for metallic cations. Nature . 172, 201-211. 
Ayad, M.; El-Sadik, M. ; Mostaffa, S. (1986). 4-Aminoantipyrine as an analytical reagent for the colorimetric determination of tetracycline and oxytetracycline. Anal. Lett., 19, 2169-2181.

" British Pharmacopeia on CD- ROM ", (2000). 3rd edn., System Simulation Ltd, the stationary office, London,

Hargis, L.G. (1988). "Analytical Chemistry Principles and Techniques". Prentice-Hall Inc, New Jersey, 424-427 p.

Innocenzo, G.; Fabio, P. (2009). Determination of tetracycline residues by liquid chromatography coupled with electrochemical detection and solid phase extraction. J. Agric. Food Chem.,57(19), 8735-8741.

Johnathan, W.; Yugang, Z. (2007). Simultaneous determination of tetracycline, oxytetracycline and 4-epitetracycline in milk by high-performance liquid chromatography . Food Chem. , 103, 1297-13.

Jose, L.; Patricia, L.; Helena, R.; Pezza, L. (2009). Flow injection spectrophotometric determination of tetracycline and doxycycline in pharmaceutical formulations using chloramines-T as oxidizing agent. Quim Nova, 32(7), 1764-1769.

Kazo, I.; Norio, O.; Mitsuru, Y. (1992). Determination of tetracycline antibiotics by reversed phase high-performance liquid chromatography with fluorescence detection. J. Chromatog. A, 623, 153-158.

Khairi, F. (2008). Analysis of tetracycline and oxytetracycline through charge transfer complexation . Amer. J., 3 (3), 212-218.

Parviz, N.; Reza, M.; Parandis, D. (2007). " FFT -Adsorptive voltamatric technique for pico-level determination of tetracycline in capsules at an micro electrode in flowing solutions" . Turk. J . Chem., 31, 279-291.

Pena, A.; Lino, M.; Alonso, D.; Barcelo, D. (2007). Determination of tetracycline antibiotic residues in edible swine tissues by liquid chromatography with spectrofluorometric detection and confirmation by mass spectrometry, J. Agriculture and Food Chem. , 55, 4973-4979

Prinya, M.; Saisunee, L.; Suphachock, U. (2008). Spectrophotometic flow-injection analysis assay of tetracycline antibiotics using a dual light -emitting diode based detector . Mj. Int. J. Sci.Tech. , 2 (1), 201-209

Regos, A. ; Zuk, G. ; Lukasiak, J. D. (1978). "Flourimetric determination of tetracycline hydrochloride". Sci. Pharm., 46,249-254; Anal. Abst. (1979), 37, 1 E37.

Ronald, B. (2007). Determining trace levels of tetracycline in solid and liquid samples utilizing complexation with transition metal cation. Anal. Chem., 3, 4-6.

Saisunee, L.; Boonsom L.; Surasat W.; Wirt R. (2006). Flow injection spectrophotometric determination of tetracycline in a pharmaceutical preparation by complexation with aluminium III. .Anal .Sci.22,15-18.

Shalaby, A. ; Ndia, A.; Abou-Raya, S.; Wafaa, H. ; Mehaya, F . (2011). Validation HPLC method for determination of tetracycline residue in chicken meat and liver. Food Chem. , 124(4), 1660-1666.

Yongnian, Ni .; Dong, Na. ; Serge, K. (2010). " A simple kinetic spectrophotometric method for simultaneous determination of tetracycline by use of chemometrics". Anal. Methods , 2 ,1302 -1309. 